\title{
The Lack of Effective Remedies at the European Court of Human Rights after Opinion 2/13
}

\author{
Dalia Palombo"
}

\section{Introduction}

This article investigates whether, after Opinion $2 / 13,{ }^{1}$ victims have effective means of redress at the European Court of Human Rights (ECtHR) when the European Union (EU) violates their fundamental rights. In Opinion $2 / 13$, the Court of Justice of the European Union (CJEU) dismissed the Draft revised agreement on the accession of the European Union to the Convention for the Protection of Human Rights and Fundamental Freedoms (Draft Agreement), ${ }^{2}$ which was the product of more than four years of negotiations between the European Commission (EC) and the Council of Europe. A number of human rights and EU scholars have already analysed the detrimental consequences that Opinion 2/13 may have on the institutional relationship between the EU and the Council of Europe. ${ }^{3}$ What receives less attention is that the Draft Agreement, if effective, would have entitled victims of human rights abuses to file complaints against the EU at the ECtHR. This article analyses what avenues Opinion 2/13 left for perspective

* LSE Fellow at the London School of Economics and Political Science, Department of Law. I would like to thank Ms. Edith Wagner for presenting with me a critical assessment of Opinion 2/13 at the Max Planck Institute Luxembourg for Procedural Law. The content of this article is based in part on the research made for our joint presentation. However, please note that the views of the author are her own.

1 Opinion of the Court of 18 December 2014, Opinion 2/13, CJEU, ECLI:EU:C:2014:2454.

2 'Fifth Negotiation Meeting between the CDDH Ad Hoc Negotiation Group and the European Commission on the Accession of the European Union to the European Convention on Human Rights' (Council of Europe 2013).

3 See B. De Witte and Š. Imamovic, Opinion 2/13 on Accession to the ECHR: Defending the EU Legal Order against a Foreign Human Rights Court, 40 European Law Review (2015), 683; P. Eeckhout, Opinion 2/13 on EU Accession to the ECHR and Judicial Dialogue: Autonomy or Autarky, 38 Fordham International Law Journal (2015), 955; A. Lazowski and R. A. Wessel, When Caveats Turn into Locks: Opinion 2/13 on Accession of the European Union to the ECHR, 16 German Law Journal (2015), 179. 
victims of human rights abuses to file a complaint when the EU violates the European Convention on Human Rights (ECHR). One possibility could be to sue the EU Member States at the ECtHR. This complaint would be based on the fact that the EU is an international organisation (IO) and therefore its Member States could bear responsibility for the human rights violations committed by the organisation. This article investigates the real-life possibilities for human rights victims to file such a complaint. First, it examines the relationship between the EU and the parties to the ECHR after Opinion 2/13. Second, it outlines the general framework as to the responsibility of Member States for the conduct of IOs. Third, it analyses the ECtHR jurisprudence on State responsibility for unlawful EU conduct. The article argues that the current human rights responsibility framework inevitably fails to provide victims with effective remedies against both the EU and its Member States.

\section{The European Union and the European Convention on Human Rights}

Although EU law ${ }^{4}$ provides the basis for fruitful judicial cooperation between the CJEU and the ECtHR, ${ }^{5}$ the reality is that the relationship between the two courts has so far been rather conflictual. ${ }^{6}$ The EU and the Council of Europe are two distinct international institutions that bind a number of different countries to meet various obligations. They have, for a long time, coexisted without conflicts because they each have different competences: the EU has historically dealt only with economic matters, while the ECtHR focuses on human rights. However, with time, the EU has increasingly regulated also the area of human rights through the case law of EU courts and, more recently, the Charter of Fundamental Rights of

4 Treaty of Lisbon amending the Treaty on European Union and the Treaty establishing the European Community 2007 (OJ C 306/01).

5 S. Douglas-Scott, The European Union and Human Rights after the Treaty of Lisbon, 11 Human Rights Law Review (2011), 645.

6 Lazowski and Wessel, supra note 3; Eeckhout, supra note 3; De Witte and Imamovic, supra note 3; D. Sarmiento, Who's Afraid of the Charter? The Court of Justice, National Courts and the New Framework of Fundamental Rights Protection in Europe, 50 Common Market Law Review (2013), 1267. 
the European Union (EU Charter). ${ }^{7}$ This results in a potential ECtHR/ CJEU conflict of jurisdictions on fundamental rights. ${ }^{8}$

To avoid this potential conflict, and to determine the role that such diverse institutions would have in detailing the human rights obligations of those States that are simultaneously members of the Council of Europe and the EU, Article 6 of the Treaty of Lisbon states:

1. The Union recognises the rights, freedoms and principles set out in the Charter of Fundamental Rights of the European Union of 7 December 2000, as adapted at Strasbourg, on 12 December 2007, which shall have the same legal value as the Treaties. The provisions of the Charter shall not extend in any way the competences of the Union as defined in the Treaties. The rights, freedoms and principles in the Charter shall be interpreted in accordance with the general provisions in Title VII of the Charter governing its interpretation and application and with due regard to the explanations referred to in the Charter, that set out the sources of those provisions.

2. The Union shall accede to the European Convention for the Protection of Human Rights and Fundamental Freedoms. Such accession shall not affect the Union's competences as defined in the Treaties.

3. Fundamental rights, as guaranteed by the European Convention for the Protection of Human Rights and Fundamental Freedoms and as they result from the constitutional traditions common to the Member States, shall constitute general principles of the Union's law. ${ }^{9}$

Article 6 of the Lisbon Treaty attempted to harmonise the ECHR and EU Charter in the following ways.

First, the content of the EU Charter includes a number of provisions that are identical to the ECHR. ${ }^{10}$

7 See e.g. Judgment of 17 December 1970, Internationale Handelsgesellschaft mbH v. Einfuhr Und Vorratsstelle für Getreide und Futtermittel, C-11/70, ECLI:EU:C:1970:114; Judgment of 14 May 1974, J. Nold Kohlen-und Baustoffgroßhandlung v. EC Commission, C-4/73, ECLI:EU:C:1974:51.

8 Sarmiento, supra note 6; Douglas-Scott, supra note 5.

9 Treaty of Lisbon amending the Treaty on European Union and the Treaty establishing the European Community supra note 4, Article 6.

10 Douglas-Scott, supra note 5; D. Anderson and C. C. Murphy, The Charter of Fundamental Rights, in A. Biondi, P. Eeckhout and S. Ripley (Eds.), EU Law After Lisbon (2012). 
As it pertains to these provisions, Article 52(3) of the EU Charter specifies that:

In so far as this Charter contains rights which correspond to rights guaranteed by the Convention for the Protection of Human Rights and Fundamental Freedoms, the meaning and scope of those rights shall be the same as those laid down by the said Convention. This provision shall not prevent Union law providing more extensive protection. $^{11}$

Accordingly, the meaning, scope, and interpretation of the provisions included in the text of both the EU Charter and the ECHR are the same. The standards required by the ECHR, as interpreted by the ECtHR, represent a minimum platform. The Treaty of Lisbon requires EU courts to interpret the EU Charter in compliance with the ECHR, but at the same time, it allows them to strengthen the human rights protection within the EU system. Therefore, EU courts can interpret the EU Charter as establishing higher human rights protection than the ECHR but cannot interpret the EU Charter in a way which would lower the standard of protection set out in the ECHR. ${ }^{12}$ By including into the EU Charter certain provisions which are identical to the ECHR, the EU Charter is de facto incorporating part of the ECHR into EU law. To a certain extent, this is the codification of a practice that EU courts had already adopted as the CJEU had increasingly applied a number of ECHR's provisions in its case law. ${ }^{13}$ The first paragraph of Article 6 establishes that the EU Charter, including those provisions reproducing parts of the ECHR, is primary EU law. Primary laws establish the EU institutional apparatus and include the treaties of the EU. ${ }^{14}$ In the EU constitutional construction, this means that the EU Charter has neither a higher nor a lower ranking than any other EU treaty. However, the EU Charter does not enlarge EU competences beyond the power already established by the other EU treaties. Therefore, the EU Charter has somehow a more limited scope than a regular treaty because it does not

11 Charter of Fundamental Rights of the European Union 2000 (OJ C 364/1), Article $52(3)$.

12 Douglas-Scott, supra note 5; Anderson and Murphy, supra note 10; Sarmiento, supra note 6.

13 See e.g. supra note 7.

14 P.P. Craig and G. De Búrca, EU Law: Text, Cases, and Materials,5th ed. (2011), 105-123; 'Sources of European Union Law' (EUR-Lex) http://eur-lex.europa.eu/ legal-content/EN/TXT/HTML/?uri=URISERV:114534\&from=BG (last visited 6 December 2018). 
enlarge the EU competences to human rights. This apparent contrast between, on the one hand, the EU endorsing the EU Charter and, on the other hand, the EU limiting the scope of such EU Charter has been resolved in the following way. The EU Charter enshrines human rights as it pertains to the application of EU law. Therefore, while EU institutions must always respect the EU Charter, the Member States must comply with it only when they implement or apply EU law. Conversely, the EU Charter does not bind the Member States when they apply or implement their domestic legislation. ${ }^{15}$

Second, Paragraph 2 of Article 6 of the Treaty of Lisbon sets out an obligation for the EU to become a party to the ECHR. One of the goals of this provision was to ensure unity and harmony between EU law and the ECHR. Once the EU is a party to the ECHR, it is subject to the judicial review by the ECtHR and, therefore, would have to ensure that its interpretation of human rights is consistent with the ECHR. ${ }^{16}$ Despite this harmony envisaged by the founders of the Treaty of Lisbon, the relationship between the ECHR and the EU has not been a happy marriage so far. ${ }^{17}$ The requirement for the EU to become a party to the ECHR did not provide for a realistic approach as to how this should actually happen. Multiple practical questions arose in connection with this accession, including, for example, in which capacity the EU could join the ECHR, given that it is not a State and it has limited competence to determine its political and legislative agenda. To address these questions, the European Commission (EC) and the Council of Europe had initiated long lasting negotiations resulting in the adoption of the Draft Agreement. ${ }^{18}$ The Draft Agreement to be entered between the Members States of the EU and the Council of Europe was supposed to detail the special role that the EU would assume as a party to the ECHR. ${ }^{19}$ The EC and the Council of Europe agreed on the text of such a Draft Agreement. However, one of the conditions to its adoption included that the CJEU would assess whether the Draft Agreement was

15 Douglas-Scott, supra note 5; Anderson and Murphy, supra note 10; Sarmiento, supra note 6.

16 Douglas-Scott. supra note 5.

17 Lazowski and Wessel, supra note 3; Eeckhout, supra note 3; De Witte and Imamovic, supra note 3; Sarmiento, supra note 6 .

18 'Fifth Negotiation Meeting between the CDDH Ad Hoc Negotiation Group and the European Commission on the Accession of the European Union to the European Convention on Human Rights', supra note 2.

19 Lazowski and Wessel, supra note 3; De Witte and Imamovic, supra note 3. 
compatible with EU law. ${ }^{20}$ The CJEU released its non-binding opinion in December 2014 and held the Draft Agreement to be incompatible with EU law. ${ }^{21}$ The CJEU opinion was so dismissive that it left no lee-way to adopt the Draft Agreement. As of today, it is not clear if, when, and on what terms the EU will become a party to the ECHR. ${ }^{22}$

Third, Paragraph 3 of Article 6 of the Treaty of Lisbon incorporates the ECHR as general principles of EU law, which are non-written sources used by EU courts to complement the interpretation of primary and secondary EU law. ${ }^{23}$ The CJEU has increasingly affirmed these principles in its jurisprudence and elevated their status to sources of EU law. ${ }^{24}$ The preamble of the EU Charter echoes the Treaty of Lisbon:

This Charter reaffirms, with due regard for the powers and tasks of the Community and the Union and the principle of subsidiarity, the rights as they result, in particular, from the constitutional traditions and international obligations common to the Member States, the Treaty on European Union, the Community Treaties, the European Convention for the Protection of Human Rights and Fundamental Freedoms, the Social Charters adopted by the Community and by the Council of Europe and the case-law of the Court of Justice of the European Communities and of the European Court of Human Rights. ${ }^{25}$

These provisions clarify that the EU institutions and the Member States have to interpret the EU Charter in compliance with the ECHR and the ECtHR jurisprudence. It is important to note the history behind such provisions. When the Member States established the EU, they did not intend to set up a human rights system, but rather a trade and economic union. When EU trade and economic norms raised human rights concerns, however, the constitutional courts of several Member States started to establish a constitutional law doctrine that essentially argued for a duality of the EU and the Member State constitutional systems. ${ }^{26}$ According to this doctrine,

20 'Fifth Negotiation Meeting between the CDDH Ad Hoc Negotiation Group and the European Commission on the Accession of the European Union to the European Convention on Human Rights', supra note 2.

21 Opinion 2/13, supra note 1.

22 Lazowski and Wessel, supra note 3,13; Eeckhout, supra note 3; De Witte and Imamovic, supra note 3 .

23 'Sources of European Union Law', supra note 14.

24 Craig and De Búrca, supra note 14, 111-113.

25 Charter of Fundamental Rights of the European Union, Preamble, supra note 11.

26 See e.g. BVerfGE 37, 2712 BvL 52/71 Solange I-Beschluß (1974); see also BVerfGE 73, 3392 BvR 197/83 Solange II-decision (1986). 
EU law prevails over national law so long as it does not violate the fundamental rights enshrined in the Member States constitutions. ${ }^{27}$ The CJEU responded to these encroachments into its territory by including, as general EU law principles, the fundamental rights as established in the constitutional traditions common to the Member States. ${ }^{28}$ Over time, the CJEU further incorporated a number of ECHR's provisions into general principles of EU law, because the ECHR sets out the human rights principles common to the EU Member States, all of them also being members of the Council of Europe. ${ }^{29}$ As a result, the Treaty of Maastricht ${ }^{30}$ and all subsequent EU treaties, including the Treaty of Lisbon, ${ }^{31}$ have formally recognised fundamental rights, as established by the ECHR and the constitutional traditions common to the Member States, as general principles of EU law.

Thus, although EU law sets out a human rights system parallel to the existing ECHR, its founders envisaged a harmonious relationship between these two different regimes. They attempted to avoid possible conflicts between the EU and the Council of Europe by including in the EU Charter a number of provisions that are identical to the ECHR; by introducing the ECHR as part of general principles of EU law; and by setting out an obligation for the EU to become a party to the ECHR. However, following Opinion $2 / 13$, it is clear that the EU will not accede to the ECHR in the near future. This results in a legal vacuum as to what remedies victims have against the EU and/or the Member States when the EU violates human rights.

27 S. Platon, The "Equivalent Protection Test": From European Union to United Nations, from Solange II to Solange I, 10 European Constitutional Law Review (EuConst) (2014), 226; P. De Hert and F. Korenica, The Doctrine of Equivalent Protection: Its Life and Legitimacy before and after the European Union's Accession to the European Convention on Human Rights, 13 German American Law Journal (2012), 874; L. Pasquet, The Jurisdictional Immunities of International Organizations and the Right to a Court in Tension: Between Conflicting Legal Rationalities and Network Coordination (2015), 190-196.

28 See e.g. supra note 7.

29 B. De Witte, The Past and Future Role of the European Court of Justice in the Protection of Human Rights, in P. Alston (ed.), The EU and Human Rights (1999); Craig and De Búrca, supra note 14, 111-113; Douglas-Scott, supra note 5; Platon, supra note 27; De Hert and Korenica, supra note 27.

30 Treaty on European Union (Maastricht), OJ C 191, 29 July 1992.

31 Treaty of Lisbon amending the Treaty on European Union and the Treaty establishing the European Community, supra note 4. 


\section{The General Framework}

It is beyond the purpose of this article to conduct a comprehensive analysis as to the responsibility of Member States for the violations committed by IOs. However, to frame the debate concerning the ECtHR jurisprudence on the responsibility of Member States for the human rights violations perpetrated by the EU, it is necessary to set up the general framework as it pertains to: (A) Article 61(1) of the Draft Articles on the Responsibility of International Organisations (DARIO); and (B) the human rights obligations arising under the ECHR.

\section{A. The Responsibility of Member States for the Conduct of International Organisations}

The debate concerning the responsibility of IOs is topical ${ }^{32}$ and, therefore, the International Law Commission has recently published the DARIO. ${ }^{33}$ Although the DARIO are non-binding principles, they are a persuasive source as to the responsibility that IOs should bear toward the international community. ${ }^{34}$ While the DARIO focuses primarily on the responsibility of IOs, they include Article 61(1) concerning the obligations of States that are members of an IO:

A State member of an international organization incurs international responsibility if, by taking advantage of the fact that the organization has competence in relation to the subject-matter of one of the State's international obligations, it circumvents that obligation by causing the

32 See e.g. A.Nollkaemper and I. Plakokefalos, Principles of Shared Responsibility in International Law: An Appraisal of the State of the Art (2014); J. M. C. Martín, The Responsibility of Members Due to Wrongful Acts of International Organizations, 12 Chinese Journal of International Law (2013), 679; A. Orakhelashvili, The Responsibility of Member-States Due to Wrongful Acts of International Organizations: A Response to Cortes Martin, 13 Chinese Journal of International Law (2014), 621.

33 International Law Commission, 'Draft Articles on the Responsibility of International Organizations' (2011) II Yearbook of the International Law Commission; M. Möldner, Responsibility of International Organizations-Introducing the ILC's DARIO, 16 Max Planck Yearbook of United Nations Law Online (2012), 281.

34 Möldner, supra note 33; J. d'Aspremont, Abuse of the Legal Personality of International Organizations and the Responsibility of Member States, 4 International Organizations Law Review (2007), 91. 
organization to commit an act that, if committed by the State, would have constituted a breach of the obligation. ${ }^{35}$

According to the DARIO, Member States are not responsible for the conduct of an IO by mere fact of being a member of the IO. However, a Member State may bear responsibility for the violations committed by the IO if the following three conditions are cumulatively met. First, the IO commits an act that if committed by a State would violate international law. Second, according to the IO's internal rules, the IO has competence over the act triggering the violation. Third, there should be a link between the wrongful conduct of the IO and the Member State. ${ }^{36}$

Article 61(1) provides an avenue for international courts to find Member States responsible for their active participation in IOs that are violating human rights. The rationale is that Member States should not take part in IOs to violate laws that they could not otherwise breach in their capacity of States. Essentially, if I apply Article 61(1) to the EU and Member State's obligations under the ECHR, States could not circumvent their obligations by arguing that it is for the EU to regulate EU law in accordance with the ECHR. A number of scholars have analysed and criticised Article 61(1) of the DARIO. ${ }^{37}$ Some commentators have pointed out that while a first version of the DARIO seemed to suggest that Member States would be responsible for their participation in IOs, the current version significantly limits the scope of the provision and has established a higher burden of proof to hold Member States responsible for the conduct of IOs. ${ }^{38}$

Therefore, although not binding, Article 61(1) sets up the basis to hold Member States responsible for the unlawful conduct of IOs. The provision restates the jurisprudence of international tribunals and establishes a high burden of proof to hold Member States responsible for the conduct of IOs.

35 International Law Commission, supra note 33, Article 61(1).

36 Ibid., Article 61, commentary; E. Paasivirta, Responsibility of a Member State of an International Organization: Where Will It End?; Comments on Article 60 of the ILC Draft on the Responsibility of International Organizations, 7 International Organizations Law Review (2010), 49, 58-60.

37 See e.g. different views Paasivirta, supra note 36; d'Aspremont, supra note 34; C. Ryngaert, The European Court of Human Rights' Approach to the Responsibility of Member States in Connection with Acts of International Organizations, 60 International \& Comparative Law Quarterly (2011), 997.

38 Paasivirta, supra note 36. 


\section{B. Human Rights Negative and Positive Obligations ${ }^{39}$}

In order to analyse the case law of the ECtHR concerning the responsibility of Member States for human rights violations committed by the EU, it is necessary to briefly explain the distinction between negative and positive human rights obligations.

Negative obligations entail a duty of non-interference. In other words: to comply with its negative obligations, a State has to refrain from acting in violation of human rights law. Conversely, in order to breach a negative obligation, the State has to act. For example, freedom from torture or slavery corresponds to the State's obligation to refrain from torturing or enslaving people. The State may breach such obligation through the action of torturing or enslaving people. ${ }^{40}$

Positive obligations entail a duty to intervene. To comply with their positive obligations, countries have to act in accordance with human rights law. Failure to act is the key element of a breach of a positive obligation; the State violates its obligations by failing to take appropriate measures to address the needs of the individuals. A State may violate its positive obligation in multiple forms. For example, the right to education corresponds to the State's obligation to build schools, pay teachers and ensure that each individual living in a given territory receives an education. The State may breach this duty by not securing schools, not paying professors, or not paying for books. ${ }^{41}$

The procedures applicable to assess whether a State violates a certain right are different in the positive and negative obligation frameworks. In the negative obligation framework, the issue is whether the State acts in vi-

39 Please note that part of this section is based on Chapter 3 of the author's Ph.D. thesis 'Business and human rights: the obligations of the European Home State', Maastricht University (2017).

40 See generally, C. Madelaine, La technique des obligations positives en droit de la convention européenne des droits de l'homme (2014); A.R. Mowbray, The Development of Positive Obligations under the European Convention on Human Rights by the European Court of Human Rights (2004); F. Sudre, Les "Obligations Positives” dans la Jurisprudence Europeenne des Droits de l'homme, 23 Revue trimestrelle des droits de l'homme (1995), 363; D. Xenos, The Positive Obligations of the State under the European Convention of Human Rights (2012); P. R. Mazzeschi, 'Responsabilité de l'état pour violation des obligations positives relatives aux droits de l'homme', 333 Collected Courses of the Hague Academy of International Law, 175 (2008).

41 ibid. 
olation of the right; whereas in the positive obligation framework, the issue is whether the State does enough to realise an aimed result. ${ }^{42}$

Every human right implies both negative and positive obligations for States. ${ }^{43}$ For example, the State breaches the human right to a healthy environment if it either actively pollutes the environment or allows a third party to pollute the environment. In the first example, the State breaches a negative obligation by polluting the environment and, accordingly, interfering with the relevant right of the people. In the second example, the State is in breach of a positive obligation because it does not effectively prevent third parties from polluting the environment. Each State has both a negative obligation not to pollute the environment and a positive obligation to prevent third parties from polluting the environment. Therefore, in the example of environmental rights and related pollution, in order to comply with its obligations under international law, a State should refrain from polluting the environment itself and at the same time actively engage to prevent third parties from polluting the environment.

It is useful to recall how the DARIO take into consideration the notion of negative and positive obligations that entail responsibility for the IO actions and failures to act. According to Article 4:

There is an internationally wrongful act of an international organization when conduct consisting of an action or omission:

(a) is attributable to that organization under international law; and

(b) constitutes a breach of an international obligation of that organization. ${ }^{44}$

The DARIO principles acknowledge that the responsibility of an IO could arise from both acts and omissions. The joint application of Article 4 and 61(1) makes it clear that a Member State may be liable for the actions or omissions of an IO. Specifically, a question will arise as to whether the Member State, the IO, or both are responsible for an action or a failure to act of the IO. In cases of negative obligations, it could be rather straight forward to understand who is violating human rights. It is the actor committing the wrongful act, i.e. either the EU or the Member State depending, for instance, on whether it is EU or Member State law which violates international law. Conversely, in cases of positive obligations, it is not that

42 ibid.

43 See generally, M. S. Carmona, The Nature of the Obligations under the International Covenant on Economic, Social, and Cultural Rights (2003); S. Fredman, Human Rights Transformed (2008).

44 International Law Commission, supra note 33, Article 4. 
easy to understand who is violating human rights, because their violation arises from a failure to act. Therefore, both the Member State and the EU could allegedly fail to regulate a particular situation or to prevent damage. The issue in these cases is to determine who exactly was supposed to act but failed to do so. As this article analyses below, the answer to this question is a matter of EU, rather than human rights, law because it is EU law that defines when the Member States, the EU, or both have the competence to regulate a certain issue. ${ }^{45}$

Therefore, the concept of negative and positive human rights obligations, and the related actions and failures to act by the State and/or the IO, are fundamental in framing the responsibility of Member States for the unlawful conduct of IOs.

\section{The Responsibility of Member States for EU Conduct}

The ECtHR analysed in detail the responsibility of the Member States for the human rights violations committed by IOs. As it pertains to the EU, a number of scholars and ECtHR judges have consistently stressed that only through the accession to the ECHR could the EU system guarantee effective protection to human rights victims. ${ }^{46}$ Against this background, this article argues that victims of human rights violations have no effective remedies against the EU.

The ECtHR jurisprudence on the responsibility of Member States for the human rights violations perpetrated by the EU seems to be an inconsistent patchwork. However, this section attempts to explain this often-puzzling jurisprudence by investigating it through the paradigms of actions and failures to act. In order to conduct such analysis, it is necessary to distinguish between two conducts: that of the State and that of the IO. This article considers three possible scenarios combining the conduct of the

45 S. Besson, The Human Rights Competence in the EU - The State of the Question after Lisbon, in Kofler G., Poiares Maduro M. and Pistone, P. (ed.), Human Rights and Taxation in Europe and in the World (2011); T Lock, End of an Epic? The Draft Agreement on the EU's Accession to the ECHR, 31 Yearbook of European Law (2012), 162.

46 Bosphorus Hava Yollari Turizm Ve Ticaret Anonim Şirketi v. Ireland, ECtHR Application No. 45036/98, Judgment of 30 June 2005, joint concurring opinion of judges Rozakis, Tulkens, Traja, Botoucharova, Zagrebelsky and Garlicki; concurring opinion of judge Ress. See also a number of scholars that consider the EU accession as a necessary step to ensure an equivalent protection De Hert and Korenica, supra note 27; Paasivirta, supra note $36,57-58$. 
State and the IO: double actions, the combination of an action and failure to act, and double failures to act. Double actions are those cases when both the Member State and the IO act; combined action and failure to act are those cases when the IO acts and the Member State fails to act; double failures to act are those cases when both the Member State and the IO fail to act. The ECtHR jurisprudence concerning the responsibility of Member States for the conduct of IOs, such as the EU, in connection with these three scenarios resulting in human rights violations could be summarised as follows.

In cases of double actions when both the IO and a Member State act, the applicable test is the presumption of equivalent human rights protection. Under this test, the IO's judicial system is presumed to provide a human rights level of protection that is equivalent to the one provided by the ECHR. However, the applicant may rebut this presumption by proving that the IO's judicial system is manifestly deficient. ${ }^{47}$

In cases of combined action and failure to act, when the IO commits an allegedly wrongful act but the Member State does nothing to prevent or stop such action, the ECtHR lacks jurisdiction ratione personae because it is the IO that commits the unlawful act, rather than the Member State. ${ }^{48}$ This interpretation focuses only on the IO's conduct and does not take into account the responsibility of the Member State for its failure to prevent an unlawful act. ${ }^{49}$

In cases of double failures to act of both the IO and the State, the ECtHR distinguishes between procedural and substantive failures. In cases of procedural failures to act, which could be considered to constitute a structural lacuna of the IO's judicial system, the ECtHR has jurisdiction over the case, and therefore the Member State may be regarded as responsible for the failures of the IO's dispute settlement system. The reason for this approach is as follows: once Member States transfer part of their judicial authority to an $\mathrm{IO}$ and empower it with decisions that affect individuals, they

47 De Hert and Korenica, supra note 27; Bosphorus Hava Yollari Turizm Ve Ticaret Anonim Şirketi v. Ireland, supra note 46; Avotins v. Latvia, ECtHR Application No.17502/07, Judgment of 23 May 2016.

48 Connolly v. 15 Member States of the European Union, ECtHR Application No.73274/01, Judgment of 9 December 2008; Boivin v. 34 Member States of the Council of Europe, ECtHR Application No.73250/01, Judgment of 9 September 2008; Saramanti v. France, Germany and Norway ECtHR Application No.78166/01, Judgment of 2 May 2007; Behrami and Behrami v. France, ECtHR Application No.71412/01, Judgment of 2 May 2007; Ryngaert, supra note 37.

49 Stichting Mothers of Srebrenica and others v. the Netherlands, ECtHR Application No.65542/12, Judgment of 11 June 2013. 
must ensure that the IO provides human rights protection equivalent to that given by the ECHR. However, a similar logic does not apply to the IO's substantive failures that cannot be interpreted in terms of a structural lacuna. Accordingly, if, for example, an IO fails to protect civilians from an armed attack, the ECtHR will interpret such failure as a decision internal to the IO and, therefore, outside of its jurisdiction. ${ }^{50}$

\section{A. Double Actions}

In double actions cases, the joint action of the State and the EU violates an applicant's right. Typically, in these cases, the Member State implemented an EU act, and therefore the issue is whether the Member State is responsible for the implementation of such act.

Given that the issue of implementation is key to these cases, it is necessary to appreciate the differences as to the application of secondary EU law, which includes regulations, directives, decisions, and recommendations. ${ }^{51}$ According to Article 288 of the Treaty on the Functioning of the European Union:

[... A] regulation shall have general application. It shall be binding in its entirety and directly applicable in all Member States. A directive shall be binding, as to the result to be achieved, upon each Member State to which it is addressed, but shall leave to the national authorities the choice of form and methods..$^{52}$

The CJEU has developed the doctrine of direct effect which establishes EU law as having direct applicability vertically, i.e. an individual could enforce EU law against the Member States; and horizontally, i.e. an individual could enforce EU law against non-state actors. ${ }^{53}$ The CJEU has detailed the doctrine of direct effect and applied it to different sources of EU law. First,

50 Ryngaert, supra note 37; Gasparini v. Italy and Belgium, ECtHR Application No.10750/03, Judgment of 12 May 2009; Cooperatieve Producentenorganisatie van De Nederlandse Kokkelvisserij UA v. Netherlands, ECtHR Application No.13645/05, Judgment of 20 January 2009; Perez v. Germany, ECtHR Application No.15521/08 Judgment of 6 January 2015; Stichting Mothers of Srebrenica and others v. the Netherlands, supra note 49; d'Aspremont, supra note 34 .

51 Craig and De Búrca, supra note 14, 105-123 and 184-223; 'Sources of European Union Law, supra note 14.

52 Consolidated versions of the Treaty on European Union and the Treaty on the Functioning of the European Union - 2012 (OJ C326), Article 288.

53 Craig and De Búrca, supra note 14, 105-123 and 184-223. 
it set out that primary EU law is directly applicable both vertically and horizontally. Second, by interpreting Article 288, it established the different effects that EU secondary law could have. While regulations are, in principle, directly applicable both vertically and horizontally, the legal effect of directives is more nuanced because they require implementation by the Member States. It is beyond the purpose of this article to summarise the CJEU jurisprudence concerning the legal effect of directives; however, it would suffice to recall that when directives are sufficiently detailed, and Member States fail to implement them, such directives may also have vertical direct effect. ${ }^{54}$

This section analyses three cases that map out the evolution of the ECtHR jurisprudence as it pertains to the liability of Members States for actions taken in compliance with the obligations arising from a binding decision of an IO. The first case is Bosphorus, ${ }^{55}$ the leading ECtHR case concerning the relationship between the EU and its Member States. The second case is Michaud, ${ }^{56}$ which further specifies the requirements set out in Bosphorus regarding the responsibility of Member States for implementing EU law. The third case is Avotins, ${ }^{57}$ which confirmed to a significant extent the Bosphorus decision. As analysed by Cedric Ryngaert, in all of these cases the ECtHR entitles human rights victims with the possibility to file a complaint against the Member State, but at the same time it establishes a high burden of proof for the applicant to rebut the presumption that the IO provides a human rights protection equivalent to that guaranteed by the ECHR. The applicant has, in fact, to prove that the IO is manifestly deficient in providing effective adjudicative mechanisms. ${ }^{58}$

54 Ibid.,184-223; G. Betlem and A. Nollkaemper, Giving Effect to Public International Law and European Community Law before Domestic Courts: A Comparative Analysis of the Practice of Consistent Interpretation, 14 European Journal of International Law (2003), 569.

55 Bosphorus Hava Yollari Turizm Ve Ticaret Anonim Şirketi v. Ireland, supra note 46.

56 Michaud v. France, ECtHR Application No.12323/11, Judgment of 6 March 2013.

57 Case of Avotins v. Latvia, supra note 47.

58 Ryngaert, supra note 37; Paasivirta, supra note 36; De Hert and Korenica, supra note 27. 


\section{Bosphorus}

In Bosphorus, the applicant was a Turkish airline company that leased two aircraft from Yugoslavian Airline, the national airline of the Former Republic of Yugoslavia. Under the United Nations (UN) Security Council (SC) Resolution 820 sanctioning regime, the EC enacted Regulation 144/1993 prohibiting trade with the Former Republic of Yugoslavia. In connection with the implementation of this regulation, Ireland impounded one of the applicant's aircraft, which stationed in its territory. The applicant challenged this act before the Irish courts, which referred the matter to the CJEU for a preliminary ruling. The CJEU confirmed Regulation 144/1993 applied to the aircraft and, therefore, the impoundment by the Irish complied with EU law. The Member State had no discretion to implement the EU Regulation and therefore the ECtHR had effectively to decide whether Ireland was responsible for EU's actions. ${ }^{59}$ The ECtHR delivered its judgment in three main parts.

First, the ECtHR set out that it is the State's choice to delegate the power to enact laws to IOs, rather than to preserve such power for itself. Ireland voluntarily chose to regulate its UN sanctioning regime through EU law instead of national law. Such a choice could not provide an excuse for Ireland to avoid the ECtHR scrutiny over the relevant EU acts. Therefore, the ECtHR had jurisdiction over the case and, in principle, the Member States could be responsible for giving direct effect to an EU Regulation violating the ECHR. Conversely, given that the EU is not a party to the ECHR, the ECtHR had no jurisdiction to evaluate whether or not the EU itself had violated human rights. ${ }^{60}$

Second, the ECtHR established the presumption of equivalent human rights protection test. According to this test, a State is presumed to comply with the ECHR while implementing an EU act, as long as the EU's judicial system of review provides for a human rights protection which is equivalent to the one given by the ECtHR. ${ }^{61}$ In its judgment, the ECtHR recognised that EU law does not entitle individuals to a right of access to the CJEU comparable to the individual complaint procedure provided by the ECHR. However, it still held that the EU's judicial system provides overall equivalent human rights protection to that of the ECtHR, because domes-

59 Bosphorus Hava Yollari Turizm Ve Ticaret Anonim Şirketi v. Ireland, supra note 46, paras.11-101.

60 Ibid.,151-154; De Hert and Korenica, supra note 27.

61 De Hert and Korenica, supra note 27. 
tic courts entitle individuals affected by EU law with effective remedies. ${ }^{62}$ It is important to recall that the EU's judicial system includes both EU treaties based tribunals and domestic courts. Both courts must implement EU law. However, given the limited possibilities for individuals to directly file complaints in EU treaties based tribunals, ${ }^{63}$ it is often for domestic courts to apply EU law to specific cases. ${ }^{64}$ This issue was particularly sensitive as seven judges wrote concurring opinions underlining the differences between the individual right to access court provided by the ECtHR and the much lower level of protection accorded by EU law. ${ }^{65}$ Although all of the judges agreed on the outcome of the case, as the presumption of equivalent human rights protection is rebuttable and therefore EU law is not immune from the ECtHR judicial review, it is important to note that the ECtHR was concerned with the limited scope of the right of individuals to access courts in the EU's judicial system. Specifically, the concurring opinions called for the EU to become a party to the ECHR as the necessary step to ensure an effective human rights protection within the EU's judicial system. ${ }^{66}$

Third, an applicant may rebut the presumption of equivalent human rights protection by demonstrating that the protection provided by EU law is manifestly deficient. ${ }^{67}$ So far, the ECtHR has never found a Member State responsible because an IO provided a manifestly deficient protection to human rights victims. ${ }^{68}$ The only case where the ECtHR recognised that

62 Bosphorus Hava Yollari Turizm Ve Ticaret Anonim Şirketi v. Ireland, supra note 46, paras. 155-167.

63 K. Gutman, The Evolution of the Action for Damages against the European Union and Its Place in the System of Judicial Protection, 48 Common Market Law Review (2011), 695.

64 Craig and De Búrca, supra note 14, 184-223; Betlem and Nollkaemper, supra note 54.

65 Bosphorus Hava Yollari Turizm Ve Ticaret Anonim Şirketi v. Ireland, supra note 46, joint concurring opinion of judges Rozakis, Tulkens, Traja, Botoucharova, Zagrebelsky and Garlicki; concurring opinion of judge Ress.

66 Ibid. See also a number of scholars that consider the EU accession as a necessary step to ensure an equivalent protection; De Hert and Korenica, supra note 27; Paasivirta, supra note 36 .

67 Ryngaert, supra note 37, 1000-1003; De Hert and Korenica, supra note 27; Bosphorus Hava Yollari Turizm Ve Ticaret Anonim Şirketi v. Ireland, supra note 46, paras. $155-156$.

68 De Hert and Korenica, supra note 27, 886-889; C. Ryngaert, The European Court of Human Rights' Approach to the Responsibility of Member States in Connection with Acts of International Organizations, 60 International \& Comparative Law Quarterly (2011), 997, 1000-1003. 
the applicant rebutted the presumption was Al-Dulimi and Montana Management Inc. In this case, the ECtHR held the UN sanctions regime manifestly deficient in terms of human rights protection. ${ }^{69}$ Although scholars have celebrated the decision as ground-breaking, ${ }^{70}$ the ECtHR Grand Chamber reversed it. The ECtHR Grand Chamber held that the UN sanctions regime was not manifestly deficient and it was for the Member State, Switzerland, to interpret it in compliance with the ECHR. However, given that Switzerland applied the sanctions regime in a way that was detrimental to the applicant, it violated the ECHR. ${ }^{71}$ Therefore, it is still unclear what the exact meaning of manifestly deficient is and what the conditions are to rebut the presumption of equivalent human rights protection. ${ }^{72}$

\section{Michaud}

In Michaud, France implemented the EU anti-money laundering directives in a way that required French lawyers to report suspicious money laundering transactions to the French authorities. The applicant argued that the obligation to report violated the client-attorney privilege covered by Article 8 of the ECHR. One of the issues that the applicant raised was whether the rule in Bosphorus applied not only to directly applicable EU law, such as regulations, but also to directives, which, as a general rule, have no direct effect and must be implemented by the Member States so as to create rights and obligations for individuals. ${ }^{73}$

The ECtHR distinguished Michand from Bosphorus because in Michand the State responsibility would depend not on its participation in the EU, and, therefore, on whether or not EU law provided an equivalent human rights protection to the applicant, but instead on the conduct that the State itself adopted to implement the EU directive in its domestic system. Furthermore, in Michaud French courts did not seek a preliminary ruling at the CJEU and, therefore, the applicant did not have the possibility to fully enjoy the EU's judicial system, but had access limited to domestic courts.

69 Al-Dulimi and Montana Management Inc v. Switzerland, ECHR Application No.5809/08, Judgment of 26 November 2013.

70 Platon, supra note 27; Pasquet, supra note 27, 190-196.

71 Al-Dulimi and Montana Management Inc v. Switzerland, ECHR Application No.5809/08, Judgment of 21 June 2016.

72 De Hert and Korenica, supra note 27; Platon, supra note 27.

73 Michaud v. France, supra note 56; Bosphorus Hava Yollari Turizm Ve Ticaret Anonim Şirketi v. Ireland, supra note 46. 
The ECtHR assessed the specific case by taking into account the sole responsibility of the Member State as the directives were general enough to be interpreted in different ways, and, therefore, France could have implemented such directives in compliance with the ECHR. ${ }^{74}$

Michaud is not a unique case. The ECtHR has consistently held that when a Member State has the discretion to implement an international obligation, it should interpret it in compliance with the ECHR. For instance, in the context of the UNSC resolutions, the ECtHR established a presumption that the UN and the SC do not require States to violate human rights. Therefore, it is possible for States to interpret any obligation arising out of a SC Resolution in a way that complies with the ECHR. On this basis, the ECtHR held in cases such as Al-Jedda, ${ }^{75}$ or Al-Dulimi and Montana Management Inc. ${ }^{76}$ that the Member State violated the ECHR by wrongly interpreting a SC Resolution. Note that this was possible because, differently from Bosphorus where an EU regulation implemented the SC Resolution, in Al-Jedda and Michaud, the IO allowed the Member State certain discretion as to the practical implementation of the international obligation. Interestingly, as it pertains to Al-Dulimi and Montana Management Inc., the Chamber and the Grand Chamber of the ECtHR disagreed as to whether the UNSC left the Member State with some discretion in implementing and interpreting the SC Resolution. ${ }^{77}$ As mentioned above, while the Chamber decided that the UNSC resolution was manifestly deficient, the Grand Chamber held that the UNSC left the Member State with certain discretion to interpret the Resolution in compliance with the ECHR. Therefore, it was the Member State, and not the UN, to blame for implementing the Resolution in a manifestly deficient way. ${ }^{78}$

\section{Avotins}

In Avotins, the applicant was an individual from Latvia who borrowed from a company incorporated in Cyprus. The company won a case in

74 Michaud v. France, supra note 56, paras. 112-116.

75 Al-Jedda v. The United Kingdom, ECtHR Application No.27021/08, Judgment of 7 July 2011.

76 Al-Dulimi and Montana Management Inc. v. Switzerland, supra note 71.

77 Ibid., Al-Dulimi and Montanta Management Inc. v. Switzerland, supra note 69.

78 Platon, supra note 27; Al-Dulimi and Montanta Management Inc. v. Switzerland, supra note 69; Al-Dulimi and Montana Management Inc. v. Switzerland, supra note 71 . 
Cypriot courts against the applicant and sought to enforce the Cypriot judgment in Latvia. Under the EU Brussels I Regulation, the Latvian Supreme Court enforced the Cypriot judgment. It held that domestic courts had no authority to review foreign judgments under the Brussels I Regulation, but should have simply enforced them. The applicant alleged that by doing so, Latvia violated Article 6 of the ECHR as the Cypriot court decided the judgment in absentia. ${ }^{79}$ There are two interesting aspects of Avotins. First, it is a case that reassessed the Bosphorus test after the CJEU Opinion 2/13. Second, Avotins is, on the one hand, similar to Bosphorus, as it concerned an EU regulation directly applicable in the Member States, but, on the other hand, similar to Michaud, as Latvian courts had not requested a CJEU preliminary ruling and, therefore, the applicant did not have the possibility to enjoy the full protection of the EU human rights judicial system.

As to the first aspect, the ECtHR confirmed the presumption that the EU judicial system offers a human rights protection equivalent to the one that individuals enjoy under the ECHR. However, the ECtHR clarified that the applicants could rebut such presumption in the context of the mutual recognition of foreign judgments because the EU Member States are not supposed to blindly enforce foreign judgments without first assessing whether they comply with the ECHR. In essence, the ECtHR held the Brussels I Regulation could violate the ECHR if applied blindly without first assessing whether or not a foreign judgment violates human rights. In the ECtHR's words:

[The ECtHR m] ust verify that the principle of mutual recognition is not applied automatically and mechanically [... $\mathrm{t}$ ] o the detriment of fundamental rights $[\ldots$ W] here the courts of a State which is both a Contracting Party to the Convention and Member State of the European Union are called upon to apply a mutual recognition mechanism established by EU law, they must give full effect to that mechanism where the protection of Convention rights cannot be considered manifestly deficient. However, if a serious and substantiated complaint is raised before them to the effect that the protection of a Convention right has been manifestly deficient and that this situation cannot be remedied by European Union law, they cannot refrain from examining the complaint on the sole ground that they are applying EU law. ${ }^{80}$

79 Case of Avotins v. Latvia, supra note 47, paras. 14-68.

80 Ibid., 116. 
According to Avotins, domestic courts must conduct a human rights check of any foreign decision notwithstanding the fact that this check may violate EU law. Although Avotins has not modified the Bosphorus test, it has clarified what a manifestly deficient protection is. The protection provided by EU law is manifestly deficient if it requires domestic courts to blindly apply a foreign judgment without first assessing whether that judgment effectively complies with the ECHR. However, in Avotins, the Cypriot judgment respected human rights and, therefore, Latvia enforced it in compliance with both EU law and the ECHR. ${ }^{81}$

As to the second aspect, the ECtHR clarified that in order to ensure a level of human rights protection equivalent to the one provided by the ECHR, domestic courts do not necessarily need to seek for a preliminary ruling by the CJEU. The status of domestic courts as part of both the national and EU judicial systems allow them to apply EU law, including EU human rights law. ${ }^{82}$

Essentially, in Avotins the ECtHR confirmed the Bosphorus presumption that the EU system provides individuals with a human rights protection equivalent to the one enjoyed under the ECHR.

Therefore, an applicant may successfully file a complaint against a Member State implementing an EU secondary rule under the following alternative conditions. The applicant could overcome the presumption of equivalent protection by proving that the EU's judicial system is manifestly deficient because it does not provide effective remedies comparable to the one required by the ECHR. This is an extremely high burden of proof on the victim given that so far nobody has been able to rebut the presumption of equivalent human rights protection. Alternatively, the applicant could argue the Member State violates the ECHR because of the way it implements the EU secondary rule. The latter is a better strategy as the applicant alleviates the ECtHR from the burden to evaluate whether the EU is responsible for a human rights violation, and therefore, it is more likely to be successful in holding the Member State accountable.

\section{B. Combined Action and Failure to Act}

The second scenario may be classified as combined action and failure to act because the IO acts while the State fails to act. The Member State fails to 
prevent the IO from violating the ECHR. In these cases, the responsibility of the Member State arises from its failure to prevent or stop the IO from committing an unlawful act.

The ECtHR consistently held that deciding on the responsibility of the State for its membership in an IO would entail assessing the liability of the IO itself. In these cases what is at stake is, in the first place, the responsibility of the IO and, therefore, the ECtHR lacks jurisdiction ratione personae over the IO. Essentially, in order to assert jurisdiction, the ECtHR requires a Member State's action. ${ }^{83}$

In Behrami and Saramati, two cases decided at the same time, a number of applicants from Kosovo alleged that France, Germany, and Norway were responsible for, first, failing to prevent the explosion of a bomb, which killed Mr Behrami and, second, for detaining Mr Saramanti. In these cases, the UNSC Resolution 1244 authorised NATO military intervention in the Former Republic of Yugoslavia. ${ }^{84}$ Therefore, they were not the countries themselves that allegedly violated the ECHR, but NATO, an IO, empowered by a UNSC Resolution. The ECtHR held:

Since operations established by the UNSC Resolutions under Chapter VII of the UN Charter are fundamental to the mission of the UN to secure international peace and security and since they rely for their effectiveness on support from member states, the Convention cannot be interpreted in a manner which would subject the acts and omissions of Contracting Parties which are covered by UNSC Resolutions and occur prior to or in the course of such missions, to the scrutiny of the Court. To do so would be to interfere with the fulfilment of the UN's key mission in this field including, as argued by certain parties, with the effective conduct of its operations. It would also be tantamount to imposing conditions on the implementation of a UNSC Resolution which were not provided for in the text of the Resolution itself. This reasoning equally applies to voluntary acts of the respondent States such as the vote of a permanent member of the UNSC in favour of the relevant Chapter VII Resolution and the contribution of troops to the security mission: such acts may not have amounted to obligations flowing from membership of the UN but they remained crucial to the

83 Ryngaert, supra note 37.

84 Behrami and Behrami v. France, supra note 48, paras. 2-7; Saramanti v. France, Germany and Norway, supra note 48 , paras. $2-17$. 
effective fulfilment by the UNSC of its Chapter VII mandate and, consequently, by the UN of its imperative peace and security aim. ${ }^{85}$

The ECtHR adopted the same approach in Connolly ${ }^{86}$ and Boivin, ${ }^{87}$ two cases concerning the proceedings for employment and disciplinary sanctions of two IOs: the EU and the European Organisation for Safety and Navigation. The applicants brought their cases against a number of States that were parties to these IOs. The ECtHR held in both cases that it did not have jurisdiction ratione personae over the conduct of either the IO or the Member States of such organisation. ${ }^{88}$ Therefore, when an EU act, which does not require any form of implementation by the Member States, such as an EU primary rule, violates human rights, the victims have no remedy at the ECtHR. The ECtHR has no jurisdiction over the Member State which fails to prevent the EU from violating human rights because asserting jurisdiction over the Member State would entail indirectly asserting jurisdiction also over the EU. As a result, the applicants cannot file a complaint against either the EU, as it is not a party to the ECHR, or the Member State, and they are left with no means of redress.

Cedric Ryngaert justifies the ECtHR's approach on the basis of Article 61(1) of the DARIO principles. According to him, if the ECtHR asserted jurisdiction over cases such as Connolly and Boivin, it would open the door to holding a State accountable for the simple fact of being a member of an IO and this would be inconsistent with Article 61(1). ${ }^{89}$ I do not find Ryngaert's interpretation persuasive, because, while it is true that Member States should not be held accountable for the mere fact of being a party to an IO, the ECtHR could potentially assess their responsibility for their failure to act within an IO. While the ECtHR has consistently held that both the actions and omissions of Member States are to be considered as conduct for the purpose of determining their responsibility under the ECHR, ${ }^{90}$ the ECtHR jurisprudence concerning the accountability of Member States for the conducts of IOs seems to ignore the Member States' fail-

85 Behrami and Behrami v. France, supra note 48, para. 149; Saramanti v. France, Germany and Norway, supra note 48, para. 149.

86 Connolly v. 15 Member States of the European Union, supra note 48.

87 Boivin v. 34 Member States of the Council of Europe, supra note 48.

88 Ibid.; Connolly v. 15 Member States of the European Union, supra note 48.

89 Ryngaert, supra note 37, 1011-1015.

90 See Fredman, supra note 43; Xenos, supra note 40; Mazzeschi, supra note 40; Sepúlveda Carmona, supra note 43; see e.g. Report of the Human Rights Committee General Assembly Thirty-Sixth Session Supplement No. 40 (A/36/40), 1981. 
ures to act. The ECtHR requires a Member State's action to assert jurisdiction over a case, while a Member State's failure to prevent or influence the conduct of IOs is not a basis for establishing jurisdiction ratione personae. This is inconsistent with the ECtHR jurisprudence on positive obligations and with the responsibility of States for their failures to act.

\section{Double Failures to Act}

The third scenario may be labelled as double failures to act because both the State and the IO fail to act. From a human rights perspective, the issue is whether or not the failure to act violates the ECHR. From an EU perspective, the issue is whether it is within the competences of the Member State, the EU, or both, to act. Although the issue of competences was topical in Opinion $2 / 13,{ }^{91}$ the jurisprudence of the ECtHR has not focused on these double failures to act situations so far. However, what results from an analysis of the ECtHR case law and Opinion 2/13 is a deadlock situation: the ECtHR lacks competence to decide these double failures to act cases.

There are a few ECtHR cases which refer to double failures to act. For instance, in Bosphorus, although the case concerned a regulation implemented by the Member State and therefore a double actions type of situation, the ECtHR established that the EU's judicial system is presumed to entitle victims to a human rights protection equivalent to the one provided by the ECHR. ${ }^{22}$ In Avotins, the ECtHR stated that the applicant might rebut the presumption of equivalent human rights protection and the Member State has an obligation to check whether or not the EU's judicial system is manifestly deficient. Such an evaluation entails an assessment of the failures of the EU's judicial system. ${ }^{93}$ This aspect of the Bosphorus decision becomes more visible when taking into consideration the cases of Gasparini, ${ }^{94}$ Kokkelvisserij ${ }^{95}$ and Perez ${ }^{96}$ In these cases, the ECtHR assessed whether a Mem-

91 Opinion 2/13, supra note 1, 13; Lazowski and Wessel, supra note 3; Eeckhout, supra note 3; De Witte and Imamovic, supra note 3.

92 Bosphorus Hava Yollari Turizm Ve Ticaret Anonim Şirketi v. Ireland, supra note 46.

93 Avotins v. Latvia, supra note 47.

94 Gasparini v. Italy and Belgium, supra note 50.

95 Cooperatieve Producentenorganisatie van De Nederlandse Kokkelvisserij U.A. v. Netherlands, supra note 50.

96 Perez v. Germany, supra note 50. 
ber State was responsible for what Cedric Ryngaert describes as a structural lacuna, or in other words, a failure of the IO's judicial system. ${ }^{97}$

In Kokkelvisserij, the applicant alleged that the EU's judicial system had violated his procedural rights as he was not entitled to rebut the Advocate General's Opinion before the decision of the CJEU. The complaint alleged a failure of the EU's internal judicial system. The ECtHR distinguished this case from Boivin and Connolly on two grounds. First, while in Boivin and Connolly, the applicants complained about a decision made by the IO; in Kokkelvisserij, the applicant complained about the procedural guarantees provided by the IO's judicial system. ${ }^{98}$ According to Bosphorus, Member States must ensure that the judicial system of an IO provides human rights protection equivalent to the one provided by the ECHR. ${ }^{99}$ Therefore, when the procedural guarantees provided by the dispute settlement mechanism of an IO are at stake, the ECtHR has jurisdiction over the case as the Member State must guarantee human rights protection that is equivalent to the one provided by the ECHR. ${ }^{100}$ Second, in Kokkelvisserij, domestic courts triggered the EU's judicial proceedings through a request for a preliminary ruling. ${ }^{101}$ Therefore, in contrast to the cases Boivin and Connolly, domestic courts were themselves involved in the EU's judicial proceedings. This is certainly the case given that Member State courts are part of the EU's judicial system and Member States are involved in any domestic proceeding raising an EU question, whether or not a domestic judge requests for a CJEU preliminary ruling. ${ }^{102}$

The ECtHR confirmed this approach in Gasparini ${ }^{103}$ where the applicant alleged a structural lacuna in the NATO's dispute settlement mechanism. In contrast to the EU, the NATO's dispute settlement mechanism does not include the possibility for domestic courts to request a preliminary ruling and, therefore, domestic courts were not involved in the pro-

97 Ryngaert, supra note 37, 1003-1006.

98 Cooperatieve Producentenorganisatie van De Nederlandse Kokkelvisserij U.A. v. Netherlands, supra note 50; Boivin v. 34 Member States of the Council of Europe, supra note 48; Connolly v. 15 Member States of the European Union, supra note 48.

99 Bosphorus Hava Yollari Turizm Ve Ticaret Anonim Şirketi v. Ireland, supra note 46.

100 Ryngaert, supra note 37, 1003-1006.

101 Cooperatieve Producentenorganisatie van De Nederlandse Kokkelvisserij U.A. v. Netherlands, supra note 50.

102 Ryngaert, supra note 37, 1003-1006.

103 Gasparini v. Italy and Belgium, supra note 50. 
ceedings internal to the IO. ${ }^{104}$ Despite the lack of involvement of the national courts, the ECtHR asserted jurisdiction over the case as

[... t] he Court, in reality had to ascertain whether the respondent States, at the time they joined NATO and transferred to it some of their sovereign powers, had been in a position, in good faith, to determine the NATO's internal dispute resolution mechanism did not flagrantly breach the provisions of the Convention. ${ }^{105}$

The Perez ${ }^{106}$ case is similar to Gasparini. Like in Gasparini, the applicant, who was a UN employee, alleged a structural failure in the UN's internal dismissal proceedings, and like in Gasparini, Member States had not been involved in the proceedings. The ECtHR restated the same principles developed in Gasparini: Member States are responsible for ensuring that the IO provides the applicant human rights protection equivalent to the one given by the ECHR's system. Therefore, the ECtHR has jurisdiction over cases concerning a structural failure of the IO's internal system. In both Perez and Gasparini, the ECtHR asserted jurisdiction but then dismissed the cases as the NATO and the UN's internal proceedings were not manifestly deficient. ${ }^{107}$ In essence, the ECtHR applied the presumption of equivalent human rights protection established in Bosphorus and decided that the applicants were not able to rebut the presumption in the circumstances of the specific cases considered by the ECtHR. ${ }^{108}$ The ECtHR established that, while the Member States are not responsible for the decisions made by the organs of IOs as detailed in Boivin and Connolly, they may be responsible for structural failures of the IO's internal proceedings. According to Cedric Ryngaert's analysis:

[In Gasparini... t] he Court did not [...] attempt to, identify an action by a State. It distinguished Gasparini from Boivin and Connolly. [... I] $\mathrm{n}$ Gasparini the applicant alleged a structural lacuna in the IO's internal dispute-settlement mechanism. This structural lacuna the Court would be entitled to review, in other words Member States are responsible for the structural lacunae of IO's internal procedures. ${ }^{109}$

104 Ibid.

105 Ibid., Information Note on the Court's case-law No. 119.

106 Perez v. Germany, supra note 50.

107 Ibid., Gasparini v. Italy and Belgium, supra note 50.

108 Bosphorus Hava Yollari Turizm Ve Ticaret Anonim Şirketi v. Ireland, supra note 46.

109 Ryngaert, supra note 37, 1005. 
It is important to emphasise the procedural nature of such structural lacuna. The ECtHR has jurisdiction over structural lacuna only, but it does not have jurisdiction over any other case concerning the failure to act of an IO. For instance, if an IO fails to protect individuals from human rights violations committed in a territory it controls, the ECtHR lacks jurisdiction. ${ }^{110}$ This was the case in Stichting Mothers of Srebrenica when the ECtHR had to assess whether Dutch military forces, which were controlling the territory of Srebrenica under a UN mission, were responsible for failing to prevent the massacre of more than 7000 people by the Bosnian Serb Army. The ECtHR declared the application inadmissible as it lacked jurisdiction ratione personae over the UN and the Dutch military acting in the capacity of UN forces. ${ }^{111}$ Therefore, the ECtHR applied its jurisprudence established in Behrami, Saramati, Connolly and Boivin, concerning the conduct of IOs: the ECtHR has no jurisdiction over the conduct of any IO and, therefore, dismisses all cases relating to such conduct, including both actions and failures to act.

The practical application of the ECtHR jurisprudence to these double failures to act cases are particularly complicated. Let's assume, for instance, that both the EU and the Member State fail to regulate the activities of polluting industries that are affecting the lives of a number of applicants and let's apply the ECtHR jurisprudence to such a case. In Stichting Mothers of Srebrenica, it was clear that the UN failed to act as it was in control of a territory that UN forces were supposed to secure from any attack. Conversely, in the example above about environmental pollution, neither the EU nor the Member State regulates the activities of the polluting industry. The Member State could, therefore, be responsible because it does not enact a regulation alternative to the one that the EU fails to provide. These circumstances could facilitate the applicants' complaint at the ECtHR. It is one thing to hold a Member State responsible for not controlling the decisions of an IO, but it is quite another to hold a Member State responsible for not providing an alternative remedy to the one that the IO could provide. In this example of environmental pollution, the Member State and the EU jointly fail to act, while in Stichting Mothers of Srebrenica it was the IO that failed to secure a territory under its control. When both the EU and the Member State fail to act, the problem arises in assessing which entity should act. Logically, the answer would depend on which entity is supposed, but instead failed, to act. Therefore, the question would be whether

110 d'Aspremont, supra note 34; Ryngaert, supra note 37.

111 Stichting Mothers of Srebrenica and others v. the Netherlands, supra note 49. 
the EU, the Member State, or both, are competent to regulate the polluting activities. This issue opens a Pandora's Box, given that, by determining whether the Member State or the EU are competent to act, the ECtHR would effectively interpret EU law.

The problem of the division of competences between the EU and the Member States was at stake in Opinion 2/13. ${ }^{112}$ The Council of Europe and the EC have unsuccessfully attempted to address the issue of competence in the Draft Agreement ${ }^{113}$ by proposing a co-respondent mechanism to file a complaint simultaneously against the EU and the Member States. According to the Draft Agreement, the human rights victim would file a complaint against the EU, when the ECHR violation arises from an EU primary norm, and, conversely, against the Member State when the ECHR violation arises from an EU secondary norm. In both cases, the ECHR could invite the other entity, being the Member State in cases of a breach arising from a primary norm, and the EU in cases of a violation arising from a secondary norm, to join the case as a co-respondent. The EU or the Member State could also take the initiative to propose themselves as co-respondent to the case. ${ }^{114}$ In Opinion 2/13, the CJEU found this mechanism problematic because the ECtHR would have the power to assess whether the respondent and co-respondent are jointly or separately liable. As a result, the ECtHR would effectively interpret EU law and decide who is competent to act. According to Opinion 2/13, this would entitle the ECtHR to unlawfully assess the division of competences between the EU and the Member States. ${ }^{115}$ It is important to note that the co-respondent mechanism, as proposed in the Draft Agreement, does not clarify which party should be the defendant when the EU and/or the Member State fail(s) to act through either domestic or EU law. The Draft Agreement focuses only on actions based on primary or secondary EU norms. ${ }^{116}$ Therefore, neither the Draft Agreement, nor Opinion 2/13, clarified how the ECtHR should assess whether or not a Member State was supposed to act but failed to do so. However, it is evident from Opinion 2/13 that the ECtHR lacks authority to determine the division of competences between the Member States and

112 Opinion 2/13, supra note 1.

113 'Fifth Negotiation Meeting between the CDDH Ad Hoc Negotiation Group and the European Commission on the Accession of the European Union to the European Convention on Human Rights', supra note 2.

114 Ibid.; Lock, supra note 45.

115 Opinion 2/13, supra note 1.

116 Lock, supra note 45; Besson, supra note 45. 
the EU as this issue pertains to EU law and therefore the solution proposed in the Draft Agreement does not comply with EU law.

As of today, it is unclear how the ECtHR is supposed to assess situations of failures to act. If the EU were the competent authority to act, the ECtHR would likely dismiss the case on jurisdictional grounds as it would lack jurisdiction ratione personae on the EU. If instead, the Member State was the competent authority to act, then the case would be a regular one directed against a Member State without any involvement of the EU. If the EU and the Member State were both competent, then the ECtHR would have jurisdiction on the Member State only. However, whatever analytical approach the ECtHR might take (either considering the Member State, the EU, or both competent), it would, in fact, interpret EU law. As clarified by Opinion 2/13, the ECtHR would violate EU law if it was to interpret it by assessing the division of competences between the EU and the Member State. Thus, following the logic of Opinion 2/13, the ECtHR has no option other than declaring itself incompetent to assess double failures to act cases.

\section{Conclusion}

The ECtHR constructed its jurisprudence looking forward to the EU accession to the ECHR. ${ }^{117}$ This logic is evident in Bosphorus, where a number of judges have explicitly stated that the EU will fully protect fundamental rights only through accession to the ECHR. However, unless the EU becomes a party to the ECHR, the ECtHR jurisprudence resembles a patchwork frame carefully designed for picturing accession by the EU, which is not likely to happen in the foreseeable future. The immediate result of this jurisprudence is that victims have no effective remedies when they suffered violations of their rights due to wrongful conduct of the EU. ${ }^{118}$ This happens for the following main reasons.

First, the ECtHR established a jurisdictional bar applicable to cases concerning a State's failure to act within an IO. The ECtHR requires an action of the Member State to assert jurisdiction over a case. By doing so, the ECtHR effectively disregards its jurisprudence on positive obligations according to which a State may violate human rights by failing to act. ${ }^{119}$ The EC-

117 Bosphorus Hava Yollari Turizm Ve Ticaret Anonim Şirketi v. Ireland, supra note 46.

118 De Hert and Korenica, supra note 27.

119 Fredman, supra note 43; Xenos, supra note 40; Madelaine, supra note 40. 
tHR does not assert jurisdiction over the Member State which fails to prevent the IO from violating human rights. The only note worthy exception to this principle is the recent jurisprudence on structural lacuna, which considers the Member State responsibility for the creation of an inefficient dispute settlement mechanism internal to the IO. Such a jurisprudential trend is, however, for the moment, limited to a few cases that, in the end, were all dismissed on various grounds. ${ }^{120}$

Second, the ECtHR established a strong presumption in favour of IOs when States violate human rights in order to fulfil another international obligation. The presumption of equivalent human rights protection established in Bosphorus creates a high burden of proof for an applicant who shall demonstrate that the human rights protection provided by the IO is manifestly deficient. ${ }^{121}$ To date there is no case where the ECtHR has assessed the human rights protection provided by an IO as manifestly deficient. It may be argued that after Opinion 2/13 the ECtHR has used a more assertive tone in Avotins as it effectively held that it would be possible to rebut the presumption when EU law requires the Member State to blindly recognise a foreign judgment. However, it is difficult to predict whether this line of analysis will have any practical effect for human rights victims, as in the end, the ECtHR dismissed the case. ${ }^{122}$

Consequently, the only option for human rights victims is to argue that the Member State violates alone human rights by not correctly implementing or interpreting its international legal obligations. In blaming the Member State, the applicant liberates the ECtHR from the heavy burden of indirectly assessing the responsibility of the EU. The case becomes an ordinary complaint against the Member State and, therefore, the ECtHR is not subject to any additional restriction to adjudicate it. However, this strategy may only work for those cases when the IO allows the Member State certain discretion as to the implementation of an international obligation. The issue would be whether the State interprets an international obligation, arising from its membership in an IO, in compliance with the ECHR.

120 Ryngaert, supra note 37.

121 De Hert and Korenica, supra note 27.

122 Avotins v. Latvia, supra note 47. 